\title{
MODEL PENGEMBANGAN KURIKULUM 2013 BERBASIS BUDAYA DAERAH DAN POTENSI PESERTA DIDIK SEKOLAH DASAR
}

\author{
Mujono, Acep Ruswan, Mamad Kasmad, D. Wahyudin \\ Program Studi PGSD, Universitas Pendidikan Indonesia, Kampus Purwakarta
}

\section{Kata Kunci : \\ K-13 \\ Pembelajaran Kontekstual}

\begin{abstract}
In the preliminary study, many schools have implemented and compiled $\mathrm{K}-13$ but have not conceptually focused on the potential of learners, schools and regions. This study aims to identify the potential of learners, schools and localities in developing $K-13$, develop $K-13$ design models that are oriented to the needs, and develop curriculum implementation and evaluation plans at school level according to the potential. This study uses a qualitative approach, which consists of three main steps, namely: preliminary study, development stage and testing phase. The results of research indicate that the role of education stakeholders is required continuously, through exemplary learning process, so that the culture and character transforms into scientific ways that make the teachers can not break away from $5 \mathrm{~K}$ (Convergence, Contextual, Collaboration, Connectivity and Creative Content )
\end{abstract}

Email penulis:

mujono@upi.edu

\begin{abstract}
ABSTRAK
Dalam studi pendahuluan, banyak sekolah yang telah menerapkan dan menyusun K-13 namun secara konsep belum berorientasi pada potensi peserta didik, sekolah dan daerah. Penelitian ini bertujuan untuk untuk mengidentifikasi potensi peserta didik, sekolah dan daerah dalam mengembangkan K-13, mengembangkan model disain K-13 yang memiliki orientasi pada kebutuhan, dan mengembangkan rancangan implementasi dan evaluasi kurikulum pada tingkat sekolah sesuai dengan potensi. Penelitian ini menggunakan pendekatan kualitatif, yang terdiri dari tiga langkah utama, yaitu: studi pendahuluan, tahap pengembangan dan tahap pengujian. Hasil penelitian menunjukan bahwa diperlukan peran para pemangku pendidikan secara berkesinambungan, melalui keteladanan dalam proses pembelajarannya, sehingga budaya dan karakter itu berubah menjadi cara-cata ilmiah yang membuat para guru tidak bias melepaskan diri dari $5 \mathrm{~K}$ (Konvergensi. Kontekstual, Kolaborasi, Konektivitas dan Konten Kreatif)
\end{abstract}

\section{PENDAHULUAN}

Sebagaimana dinyatakan dalam Undang-undang RI Nomor 20 Tahun 2003 tentang Sistem Pendidikan Nasional pasal 38 ayat 1 bahwa : "Kerangka dasar dan struktur kurikulum pendidikan dasar dan menengah ditetapkan oleh pemerintah". Pernyataan dalam ayat 1 tersebut di atas lebih diperjelas lagi dalam ayat 2, bahwa :

"Kurikulum pendidikan dasar dan menengah dikembangkan sesuai dengan relevansinya oleh setiap kelompok atau satuan pendidikan dan komite 
sekolah dibawah koordinasi dan supervise Dinas Pendidikan Kabupaten/kota untuk pendidikan dasar dan provinsi untuk pendidikan menengah".

Berdasarkan ketentuan di atas, pemerintah dengan berbagai kebijakanyasejak tahun 2014 telah menetapkan dan memberlakuka kurikulum 2013 untuk jenjang pendidikan dasar. Secara bertahap pemberlakukan kurikulum 2013, di jenjang pendidikan dasar akan menggunakan dan menerapkan kurikulum 2013, sehingga pada tahun 2018 semua jenjang pendidikan dasar telah secara penuh melaksanakan pembelajaran berbasis kurikulum 2013. Pusat Kurikulum (Puskur) Badan Penelitian dan, Pengembangan Departemen Pendidikan Nasional mengusulkan dan atau mengembangkan suatu model jaringan kurikulum (Jarku). Jaringan Kurikulum tersebut dikembangkan dengan tujuan membangun jaringan kerja sama antara pusat dan daerah serta antar daerah dalam pengembangan kurikulum (Balitbang Depdiknas, 2006). Secara khusus jaringan kurikulum tersebut diarahkan untuk terbentuknya tim jaringan kurikulum pada tingkat provinsi dan kota/kabupaten.

Besarnya perhatian terhadap kurikulum 2013, karena pada tingkat sekolah kurikulum adalah ujung tombak dari keberlangsungan proses pendidikan. Dalam rangka membantu proses pendidikan, maka perlu kajian tentang berbagai model dalam pengembangan kurikulum pada tingkat satuan pendidikan (sekolah), sehingga dengan penerapan model pengembangan kurikulum yang digunakan akan mempermudah pembinaan dan penerapannya.

Penelitian ini bertujuan untuk: 1) untuk menemukan cara dalam mengidentifikasi potensi peserta didik, sekolah dan daerah dalam mengembangkan K-13. Berdasarkan survey pendahuluan, banyak sekolah yang telah menerapkan dan menyusun K-13, namun secara konsep belum berorientasi pada potensi peserta didik, sekolah dan daerah; 2) Mengembangkan model disain K-13 yang memiliki orientasi pada kebutuhan peserta didik, sekolah dan daerah; 3) Mengembangkan rancangan implementasi dan evaluasi kurikulum pada tingkat sekolah seseuai dengan potensi peserta didik, sekolah dan daearah; 4) Membantu sekolah dalam pembentukan tim pengembang K-13, jika disekolah belum terbentuk tim pengembang kurikulum 2013.

\section{KAJIAN PUSTAKA}

Dalam Undang-Undang RI. Nomor 20 Tahun 2003, tentang Sistem Pendidikan Nasional, Bab I Ketentuan Umum pasal 1, ayat 19 dinyatakan bahwa yang dimaksud dengan kurikulum adalah seperangkat rencana dan pengaturan mengenai tujuan, isi dan bahan pembelajaran serta cara yang digunakan sebagi pedoman penyelenggaraan kegiatan pembelajaran untuk mencapai tujuan tertentu. Dengan kata lain, bahwa kurikulum dapat diartikan sebagai program pembelajaran pada suatu jenjang pendidikan. Pengertian di atas sejalan dengan Zais (1976, hlm. 7) yang menyatakan bahwa, "Curriculum is a racecourse of subject matters to be mastered". Kurikulum dapat pula diartikan secara sempit, yaitu sebagai silabus atau program pembelajaran suatu mata pelajaran, satuan acara perkuliahan/pembelajaran. Sejalan dengan Zais, Colombo Plan Staff College for Technician Education (1982, hlm. 9), juga mengemukakan bahwa "curriculum is the product of curriculum planning. It is a written document intended to be used by teachers for developing teaching strategies for specific groups of student". Kurikulum sebagai bentuk dukumen tertulis menjadi dasar dan bahan evaluasi untuk masa yang akan datang. Efektivitas dan efisiensi penerapan kurikulum akan diuji dan dikaji dari keberadaan dukumen pengalaman belajar peserta didik yang tertuang dalam silabus dan satuan acara perkuliahan/pembelajaran. Menurut Hasan (2004:2) pengalaman belajar/experience learning harus memberikan dampak langsung terhadap hasil belajar peserta didik. Apabila pengalaman belajar peserta didik tidak sesuai dengan rencana tertulis (silabus, satuan acara 
pembelajaran), maka hasil belajar yang diperoleh peserta didik tidak dapat dikatakan sebagai hasil dari kurikulum.

\section{Landasan Pengembangan Kurikulum}

Untuk mengembangkan suatu model kurikulum perlu adanya landasan atau hal yang mendasari, yaitu suatu pemikiran yang mendalam serta melalui kajian dan penelitian yang maksimal tentang kualitas pendidikan yang ideal. Proses pengembangan kurikulum harus didasarkan atas suatu ide atau pemikiran tertentu mengenai pendidikan. Perbedaan pemikiran atau ide akan menyebabkan perbedaan lahirnya kurikulum yang ada, baik secara dukumen maupun sebagai hasil belajar atau pengalaman belajar. Hal yang demikian lebih ditegaskan oleh Oliva (1997: hlm. 12) bahwa "curriculum it self is a construct or concept, a verbalization of an extremely complex ide or set of ideas". Permasalahan yang sering muncul adalah: 1). Ide atau pokok pikiran itu belum dirumuskan secara jelas. 2) para pengembang dukumen adalah orang yang berbeda dari penemu ide tersebut, maka apa yang diinginkan oleh orang yang memiliki ide belum dapat dipahami sepenuhnya oleh para pengembang dukumen. 3). Hal di atas melahirkan sebuah konsekuensi, pengembangan pengalaman belajar peserta didik dapat berbeda dari apa yang dikehendaki dalam rencana tertulis (Hasan, 2004: hlm. 2). Terdapat banyak ragam/dimensi dalam pengembangan kurikulum yang memperhatikan kebutuhan masyarakat/peserta didik, yaitu: 1) pengembangan ide dasar untuk kurikulum, 2) pengembangan program, 3) Silabus, 4) satuan acara perkuliahan/pembelajaran, 5) penglaman belajar/experience learning, 6) hasil belajar/learning outcomes.

Setiap usaha dalam pengembangan kurikulum tentunya tidak dapat dilepaskan dari kegiatan evaluasi. Dalam pengembangan kurikulum, evaluasi merupakan salah satu dimensi dalam proses pengembangan kurikulum. Evaluasi, pertama-tama harus diarahkan untuk mengevaluasi pengembangan dimensi ide dan program kurikulum. Evaluasi pada tahap ini dilakukan oleh seseorang atau tim yang merupakan bagian dari tim pengembang kurikulum, tetapi bukan orang yang mengembangkan dimensi-dimensi kurikulum itu. Evaluasi ini dilakukan dengan tujuan untuk mengetahui ketepatan ide/pokok pikiran dibandingkan dengan beberapa kriteria, ketepatan dan keterkaitan internal dan eksternal dari berbagai komponen program yang dikembangkan, kejelasan pedoman serta keterbacaan keseluruhan kurikulum. Pada tahap berikutnya, evaluasi diarahkan untuk mengevaluasi silabus dan SAP. Evaluasi ini dilakukan oleh dosen/ pengajar yang bertanggung jawab dalam pengembangan dimensi, walaupun ia dapat juga meminta jasa orang lain untuk melakukan evaluasi terhadap apa yang sudah dilakukannya.

Dalam pengembangan kurikulum menurut Syaodih (2002: hlm. 38-72), penyusunan dan pengembangannya membutuhkan landasan-landasan yang kuat dan mendasar yang terkait dengan landasan filosofis, psikologis, social, disesuaikan dengan kondisi dan kemajuan ilmu pengetahuan dan teknologi. Sejalan dengan pandangan filosofi, menurut Oliva (1992: hlm. 193) terdapat empat aliran filsafat pendidikan yang dominan yang dianut dalam pengembangan disain kurikulum, yaitu : reconstructionism, progressivism essentialism dan perenialisme.

Selain landasan filosofi, terdapat pula landasan psikologis. Para pendidik, instruktur, guru, dosen dan pengembang kurikulum perlu memahami keunikan dan dinamika perkembangan psikologis peserta didik. Menurut Syaodih (2003), terdapat dua hal yang perlu dipahami tentang keunikan dan dinamika perkembangan peserta didik dalam pengembangan kurikulum, yaitu bagaimana karakteristik perkembangannya (landasan psikologi perkembangan) dan bagaimana peserta didik belajar (landasan psikologi pendidikan). Psikologi perkembangan memberikan penjelasan tentang perkembangan karakteristik dan 
kemampuan-kemampuan individu mulai sejak masa bayi sampai dewasa. Sedangkan psikologi pendidikan mengarahkan berbagai konseo-konsep belajar dan pembelajaran yang sesuai untuk peserta didik yang umumnya termasuk kedalam kategori usia muda dan dewasa.

Perkembangan social, terutama kemampuan peserta didik dalam bekerja sama, kemampuan memimpin, berkomunikasi, aspek emosional dan nilai-nilai pada umumnya masih terus berkembang sampai masa dewasa, dan dalam aspek-aspek tertentu tidak lagi mengalami perkembangannya setelah usia 50 tahun. Dlam kemampuan berpikir hamper setara dengan kemampuan social. Tingkat kecerdasan, sebagai contoh, disinyalir oleh beberapa ahli, tidak akan berkembang lagi atau pertambahannya relative kecil setelah masa adolesen. Disisi lain, kualitas dan ketajaman berpikir masih terus berkembang, sesuai dengan tingkat pendidikan yang diikuti serta bidang keahlian yang ditekuninya.

Faktor lain yang perlu diperhatikan dalam pengembangan kurikulum adalah kondisi social budaya dan geografis suatu daerah. Menurut Murray Print (1993), menyatakan bahwa kurikulum merupakan konstruk dari sebuah masyarakat. Lebih lanjut Murray mengatakan :

"At one level, curriculum is an idea, a contruct of society. It is a statement of what a society values: what is want to continue, what it wants to change, what it wants to renew. Of course, even this conception of society as having an entity, a capacity to make choces, is contentious".

Berangkat dari statemen Murray tersebut di atas, maka program pendidikan atau kurikulum perlu disusun dan diimplemetasikan dengan memperhatikan kondisi dan perkembangan social budaya dimana daerah peserta didik berada. Hal ini perlu diperhatikan karena program pendidikan tersebut ditujukan untuk mempersiapkan pserta didik yang berasal dari berbagai lingkungan social budaya, untuk menguasai ilmu pengetahuan dan kemampuan agar dapat hidup dan bekerja pada berbagai lingkungan sosial budaya dimana peserta didik berada. Dalam kurikulum muatan local, dipertegas, bahwa peserta didik dipersiapkan untuk menghadapi kehidupan yang sesuai dengan pola kehidupan lingkungan dimana peserta didik berada. Keragaman kondisi geografis mempunyai pengaruh pada pertumbuhan dan perkembangan pola hidup dan kehidupan, cara-cara bekerja dan berinteraksi dan berkomunikas antar etnik, nilai-nilai social budaya.

Faktor lain yang yang perlu menjadi pertimbangan dalam pengembangan kurikulum adalah landasan ilmu pengetahuan, teknologi dan seni. Pendidikan sebagai lembaga pengembangan kemampuan profesiona, membutuhkan dukungan ilmu pengetahuan dan teknologi. Ilmu pengetahuan, teknologi dan seni menjadi isi dari kurikulum, tetapi juga merupakan penunjang proses pembelajaran. Perencanaan program pendidikan dan penyusunan disain kurikulum yang ideal harus didasarkan atas kaidah-kaidah dan prinsip-prinsip ilmu pengetahuan atau menggunakan model teknologi tertentu, sehingga program atau disain kurikulum tersebut tersusun secara sistematis, relevan dengan tuntutan perkembangan ilmu pengetahuan, teknologi yang berkembang di masyarakat.

\section{Prinsip-Prinsip Pengembangan Kurikulum}

Upaya dalam pengmbangan, seorang pengembang kurikulum biasanya menggunakan beberapa prinsip yang diyakininya sebagai acuan agar kurikulum yang dihasilkannya tersebut dapat memenuhi harapan peserta didik, lembaga pendidikan (sekolah), orang tua, masyarakat pengguna dan tidak ketinggalan bagi pemegang kebijakan pendidikan (pemerintah). Menurut Syaodih (2000: hlm. 150-152) menyebutkan bahwa terdapat dua prinsip dalam pengembangan kurikulum, yaitu 1) prinsip Umum dan 2) prinsip Khusus. Prinsip umum berkaitan dengan kebijakan dalam pengembangan kurikulum secara makro. Prinsip umum ini mencakup lima hal yng harus diperhatikan dalam pengembangan 
kurikulum, yaitu: relevansi, fleksibelitas, kontinuitas, praktis dan efektivitas. Sementara itu, Hamalik (2004: hlm. 14) menyatakan adanya beberapa prinsip dalam pengembangan kurikulum, yaitu: obyektivitas, keterpaduan, manfaat, efisiensi dan efektifitas, kesesuaian, keseimbangan, kemudahan, berkesinambungan dan pembakuan.

Berkenaan dengan prinsip relevansi, lebih lanjut Syaodih (2000: hlm. 150) menyatakan terdapat dua relevansi yang harus dimiliki oleh kurikulum, yaitu relevan didalam kurikulum itu sendiri, adanya kesesuaian antara tujuan, isi, proses penyampaian dan penilaian. Relevansi internal ini menunjukan adanya keterpaduan kurikulum. Relevan ke luar, dimaksudkan adanya kesesuaian antara tujuan, isi dan proses belajar yang termuat dalam kurikulum hendaknya relevan dengan tuntutan, kebutuhan dan perkembangan masyarakat. Kurikulum menyiapkan peserta didik untuk mengemban tugas tersebut.

Dalam upaya mengembangkan kurikulum dikenal beberapa model pengembangan yang dapat digunakan oleh para ahli kurikulum. Syaodih (2000) menyebutkan beberapa model pengembangan kurikulum yang dikenal luas oleh masyarakat antara lain: 1) The Administrative Model, 2) The Grass Roots Model, 3) Beaucham's System, 4) The Demonstration Model.

The Administrative Model atau model Top Down, merupakan model yang paling lama dan banyak digunakan dalam pengembangan kurikulum. Model ini dikenal juga dengan istilah line staff. Model ini muncul karena adanya inisiatif dan gagasan pengembangan kurikulum datangnya dari administrator pendidikan dan menggunakan prosedur administrasi. Dengan wewenang administrasinya, administrator pendidikan membentuk tim atau suatu komisi pengarah pengembang kurikulum yang beranggotakan para pejabat pendidikan, para ahli pendidikan kurikulum, ahli disiplin ilmu dan para pengusaha. Komisi pengembangan kurikulum bertugas merumuskan konsep-konsep dasar, landasan-landasan, kebijakan dan strategi utama pengembangan kurikulum. Setelah hal-hal yang mendasar tersebut dirumuskan, selanjutnya administrator membentuk tim kerja pengembangan kurikulum yang terdiri atas para ahli pendidikan/kurikulum, ahli dalam disiplin ilmu dan guru bidang studi. Tim kerja pengembang kurikulum bertugas menyusun kurikulum yang lebih operasional, dengan menjabarkan konsep-konsep dasar yang telah dirumuskan oleh komisi pengembang kurikulum. Tim kerja pengembang kurikulum merumuskan tujuan yang lebih rinci/lebih operasional, menyusun urutan bahan ajar, memilih strategi pembelajaran dan evaluasi, serta menyusun pedoman pelaksanaan kuerikulum. Hasil dari tim kerja pengembang kurikulum tersebut, dikaji ulang oleh tim pengarah, para ahli dan atau pejabat yang berwenang. Setelah memperoleh kajian yang luas dan dianggap sempurna, telah sesuai dengan konsep, landasan, kebijakan serta strategi utama yang telah ditetapkan, maka kurikulum tersebut diberlakukan.

The Grass Roots Model; merupakan kebalikan dari model pengembangan kurikulum yang pertama, yaitu inisiatif dan upaya dalam pengembangan kurikulum bersal dari guru-guru atau sekolah/lapisan bawah. Model ini berkembang dalam system pendidikan desentralisasi, yaitu ketika sekolah diberi kewenangan untuk mengembangkan kurikulum. Dalam model pengembangan ini, seorang guru atau sekelompok guru atau bahkan seluruh guru mengadakan upaya pengembangan kurikulum, baik yang berkenaan dengan suatu komponen atau komponen secara menyeluruh. Pengembangan kurikulum model ini akan memperoleh kelebihan, apabila kemampuan para guru, fasilitas, biaya maupun bahan kepustakaan telah memenuhi atau memadai dan tersedia disekolah. Gurulah yang paling berkopenten dalam menyusun kurikulum, sebab gurulah yang paling mengetahui kebutuhan peserta didiknya.

Beauchamp's System; Model ini memiliki lima langkah dalam pengembangan kurikulum, yaitu: 1) Menetapkan lingkup wilayah pengembangan, 2) Menetapkan personalia, 3) Menetapkan organisasi dan prosedur pengembangan kurikulum, 4) Implementasi kurikulum, 
yaitu melaksanakan kurikulum yang membutuhkan kesiapan guru, peserta didik, fasilitas, bahan ajar maupun biaya disamping kesiapan manajerial, dan 5) Melakukan evaluasi kurikulum.

The Demonstration Model; model ini merupakan pengembangan kurikulum yang diprakarsai oleh sekelompok guru atau sekelompok guru bekerja sama dengan para ahli, dengan maksud untuk mengadakan perbaikan kurikulum. Model ini sebenarnya adalah bersifat grassroots, inisiatif berasal dari bawah. Model ini pada umumnya berskala kecil, hanya meliputi satu atau beberapa sekolah, satu komponen kurikulum atau mencakup keseluruhan komponen kurikulum.

\section{METODE PENELITIAN}

Penelitian ini menggunakan pendekatan kualitatif, yaitu penelitian dan pengembangan (Research and Development). Menurut pendapat Borg dan Gall (1989) yang diadopsi Sukmadinata (2005: hlm. 189), secara umum penelitian ini memiliki tiga langkah utama, yaitu: studi pendahuluan, tahap pengembangan dan tahap pengujian.

Studi pendahuluan, yaitu merupakan tahap persiapan untuk merancang model. Pada tahap ini dilakukan studi kepustakaan, survey lapangan dan penyusunan produk awal atau draf model. Studi kepustakaan yang telah dilakukan adalah

Mempelajari tentang kurikulum 2013, jaringan kurikulum dan berbagai teori dalam pengembangan kurikulum. Survey lapangan akan dilakukan untuk pengumpulan data berkenaan dengan identifikasi data dasar yang perlu dikumpulkan dan dipelajari. Pada studi pendahuluan diharapkan telah tersusun peta konsep dan disain model kurikulum 2013 yang mengakomodasi atau menadaptasi kebutuhan peserta didik, sekolah dan daerah. Pada tahap ini akan dilakukan validasi tahap konsep melalui focus group discussion dengan para guru dan pengembang K-13 di sekolah.

Tahap pengembangan; merupakan tahapan untuk coba yang mewujudkan draf model pengembangan kurikulum 2013. Pada tahap ini akan dilakukan uji coba terbatas dan uji coba yang lebih luas. Hasil uji coba terbatas akan dijadikan masukan atau bahan perbaikan dan koreksi terhadap kekurangan pada saat pengembangan model. Setelah dilakukan perbaikan, akan diujicobakan lagi melalui uji coba yang wilayahnya lebih luas. Pada akhir uji coba model akan dilaksanakan seminar untuk menguji secara keseluruhan hasil uji coba.

Tahap Pengujian; dilakukan melalui eksperimen yang akan dilaksanakan di sekolah-sekolah di wilayah UPTD Cikampek, Kabupaten Karawang. Sampel pengujian akan merentang dari sekolah diwilayah barat Cikampek sampai wilayah timur Cikampek. Eksperimen akan dilaksanakan disekolah-sekolah yang belum efektif kerjanya tim pengembang kurikulum 2013.

Populasi dalam penelitian ini meliputi seluruh sekolah dasar di wilayah kerja UPTD Cikampek Kabupaten Karawang, Provinsi Jawa Barat.Sampel penelitian akan ditentukan berdasarkan teknik purposive, yaitu memilih sampel berdasarkan alasan bahwa sekolahsekolah diwilayah UPTD Kecamatan Cikampek adalah sekolah-sekolah yang digunakan untuk pelaksanaan PPL mahasiswa UPI Kampus Purwakarta tahun 2017.

\section{HASIL DAN PEMBAHASAN}

Pelaksanaan penelitian berlangsung dari bulan Oktober 2017 sampai dengan bulan Desember 2017. Penelitian dilaksanakan di Kecamatan Maniis Kabupaten Purwakarta dimana di lingkungan Kecamatan Maniis jumlah Sekolah Dasar Negeri yang melaksanakan Pembelajaran Berbasis K-13 ada 9 Sekolah Dasar, yaitu: SDN 1 Tegaldatar, SDN 
Pasirjambu, SDN 1 Citamiang, SDN 1 Gunungkarung, SDN 2 Gunungkarung, SDN 1 Ciramahilir, SDN 1 Sukamukti, SDN 1 Sinargalih dan SDN 2 Citamiang. Walaupun masingmasing Sekolah Dasar memiliki program unggulan, namun secara umum program pengembangan budaya atau pendidikan karakter relatif sama. Sebagai gambaran, ditampilkan Program Pendidikan Karakter atau pendidikan berbasis budaya yang berdasarkan Peraturab bupati No. 69 Tahun 2017 dari 9 Sekolah Dasar dilingkungan Kecamatan Maniis adalah sebagai berikut :

\section{Program Pengembangan Kurikulum 2013 Berbasis Budaya}

Program Pengembangan K-13 berbasis budaya yang dikembangkan di Sekolah Dasar adalah sebagai berikut:

\begin{tabular}{|c|c|c|c|c|c|}
\hline NO & $\begin{array}{c}\text { NAMA } \\
\text { KEGIATAN/BEN } \\
\text { TUK PERILAKU } \\
\end{array}$ & $\begin{array}{c}\text { PENANAMAN } \\
\text { KARAKTER/ } \\
\text { TUJUAN BUDAYA }\end{array}$ & SASARAN & WAKTU & KET. \\
\hline 1 & $\begin{array}{l}\text { Datang di sekolah } \\
\text { tepat jam } 06.00\end{array}$ & $\begin{array}{l}\text { Membiasakan siswa } \\
\text { bangun pagi untuk } \\
\text { menjaga kesehatan } \\
\text { (parigel) }\end{array}$ & $\begin{array}{l}\text { Siswa, guru, } \\
\text { kepala } \\
\text { sekolah dan } \\
\text { tenaga } \\
\text { kependidikan }\end{array}$ & Setiap hari & $\begin{array}{l}\text { Mengimplement } \\
\text { asikan Perbup } \\
\text { No.69 tahun } \\
2015 \text { tentang } \\
\text { pendidikan } \\
\text { berkarakter }\end{array}$ \\
\hline 2 & $\begin{array}{l}\text { 5S, Senyum, Sapa, } \\
\text { Salam, Sopan } \\
\text { Santun }\end{array}$ & $\begin{array}{l}\text { Membiasakan } \\
\text { mengucapkan salam } \\
\text { dan saling } \\
\text { mendo'akan }\end{array}$ & $\begin{array}{l}\text { Semua } \\
\text { steakholder } \\
\text { sekolah }\end{array}$ & Setiap hari & \\
\hline 3 & $\begin{array}{l}\text { Membersihkan } \\
\text { ruangan dan } \\
\text { halaman sekolah } \\
\text { sesuai jadwal piket }\end{array}$ & $\begin{array}{l}\text { Menciptakan suasana } \\
\text { lingkungan dan kelas } \\
\text { yang bersih, indah } \\
\text { dan nyaman }\end{array}$ & $\begin{array}{l}\text { Semua } \\
\text { steakholder } \\
\text { sekolah }\end{array}$ & $\begin{array}{l}\text { Sebelum masuk } \\
\text { kelas }\end{array}$ & \\
\hline 4 & $\begin{array}{l}\text { Membuka alas kaki } \\
\text { (sepatu, sandal/alas } \\
\text { kaki) }\end{array}$ & $\begin{array}{l}\text { Menjaga kebersihan, } \\
\text { kesehatan, ruangan } \\
\text { sekolah }\end{array}$ & $\begin{array}{l}\text { Semua } \\
\text { steakholder } \\
\text { sekolah } \\
\end{array}$ & Setiap hari & \\
\hline 5 & $\begin{array}{l}\text { Berbaris di depan } \\
\text { ruangan kelas } \\
\text { masing-masing } \\
\text { sebelum masuk } \\
\text { sekolah }\end{array}$ & $\begin{array}{l}\text { Membiasakan hidup } \\
\text { tertib }\end{array}$ & Siswa & $\begin{array}{l}\text { Sebelum masuk } \\
\text { kelas }\end{array}$ & \\
\hline 6 & $\begin{array}{l}\text { Pemeriksaan } \\
\text { kebersihan (kuku, } \\
\text { gigi, pakaian dll) }\end{array}$ & $\begin{array}{l}\text { Terpeliharanya } \\
\text { kesehatan jasmani }\end{array}$ & Siswa & $\begin{array}{l}\text { Sebelum masuk } \\
\text { kelas }\end{array}$ & \\
\hline 7 & Mengucapkan do'a & $\begin{array}{l}\text { Untuk mendekatkan } \\
\text { diri kepada Allah } \\
\text { SWT }\end{array}$ & Siswa, guru & $\begin{array}{l}\text { Sebelum PBM } \\
\text { dan setelah } \\
\text { PBM }\end{array}$ & \\
\hline 8 & $\begin{array}{l}\text { Membaca surat- } \\
\text { surat pendek ayat- } \\
\text { ayat suci Al-qur'an }\end{array}$ & Al-qur'an/BTQ & Siswa & $\begin{array}{l}\text { Sebelum } \\
\text { pembelajaran } \\
\text { dimulai }\end{array}$ & \\
\hline 9 & $\begin{array}{l}\text { Kegiatan GLS } \\
\text { (membaca buku } \\
\text { selama } 15 \text { menit }\end{array}$ & $\begin{array}{l}\text { Untuk memperlancar } \\
\text { kebiasaan membaca } \\
\text { dan memahami isi } \\
\text { bacaan }\end{array}$ & Guru, siswa & $\begin{array}{l}15 \text { menit } \\
\text { sebelum PBM }\end{array}$ & \\
\hline 10 & $\begin{array}{l}\text { Menyanyikan lagu } \\
\text { nasional (Indonesia } \\
\text { Raya) }\end{array}$ & Mencintai tanah air & Guru, siswa & $\begin{array}{l}\text { Sebelum } \\
\text { pembelajaran } \\
\text { dimulai }\end{array}$ & \\
\hline 11 & $\begin{array}{l}\text { Membawa bekal } \\
\text { makanan seminggu } \\
2 \text { kali hasil masakan }\end{array}$ & $\begin{array}{l}\text { Mengkonsumsi } \\
\text { makanan hasil } \\
\text { orangtuanya }\end{array}$ & Guru, siswa & $\begin{array}{l}\text { Hari Selasa, } \\
\text { Rabu karena } \\
\text { hari Senin dan } \\
\text { Kamis }\end{array}$ & $\begin{array}{l}\text { Mengimplement } \\
\text { asikan Perbup } \\
\text { No.69 tahun } \\
2015 \text { tentang }\end{array}$ \\
\hline
\end{tabular}




\begin{tabular}{|c|c|c|c|c|c|}
\hline NO & $\begin{array}{c}\text { NAMA } \\
\text { KEGIATAN/BEN } \\
\text { TUK PERILAKU }\end{array}$ & $\begin{array}{c}\text { PENANAMAN } \\
\text { KARAKTER/ } \\
\text { TUJUAN BUDAYA }\end{array}$ & SASARAN & WAKTU & KET. \\
\hline & $\begin{array}{l}\text { orang tuanya di } \\
\text { rumah (Bancakan) }\end{array}$ & $\begin{array}{l}\text { Meningkatkan rasa } \\
\text { kasih sayang orang } \\
\text { tua terhadap anaknya } \\
\text { Menghindari } \\
\text { makanan yang } \\
\text { terkontaminasi bahan } \\
\text { pengawet dan tidak } \\
\text { jajan di sekolah }\end{array}$ & & $\begin{array}{l}\text { dianjurkan } \\
\text { untuk belajar } \\
\text { berpuasa } \\
\text { Adapun } \\
\text { waktunya ketika } \\
\text { jam istirahat }\end{array}$ & $\begin{array}{l}\text { pendidikan } \\
\text { berkarakter }\end{array}$ \\
\hline 12 & Shalat dhuha & $\begin{array}{l}\text { Mendekatkan diri } \\
\text { kepada Allah SWT }\end{array}$ & $\begin{array}{l}\text { Guru, siswa } \\
\text { dan tenaga } \\
\text { kependidikan }\end{array}$ & $\begin{array}{l}\text { Waktu duha, } \\
\text { adapun } \\
\text { tempatnya di } \\
\text { dalam kelas } \\
\text { karena belum } \\
\text { tersedia } \\
\text { mushola/ } \\
\text { pelaksanaan } \\
\text { sesuai jam } \\
\text { pelajaran PAI }\end{array}$ & \\
\hline 13 & $\begin{array}{l}\text { Menabung di rumah } \\
\text { dalam bentuk } \\
\text { celengan }\end{array}$ & Hidup, hemat & Siswa & Setiap hari & $\begin{array}{l}\text { Mengimplement } \\
\text { asikan Perbup } \\
\text { No.69 tahun } \\
2015 \text { tentang } \\
\text { pendidikan } \\
\text { berkarakter }\end{array}$ \\
\hline 14 & $\begin{array}{l}\text { Pakaian sekolah } \\
\text { Senin pramuka, } \\
\text { Selasa Rabu baju } \\
\text { kampret untuk laki- } \\
\text { laki dan pakaian } \\
\text { kebaya untuk } \\
\text { perempuan, pakaian } \\
\text { batik hari Kamis, } \\
\text { pakaian koko atau } \\
\text { muslim hari Jum'at }\end{array}$ & $\begin{array}{l}\text { Pakaian pramuka } \\
\text { menerapkan rasa } \\
\text { patriotisme, pakaian } \\
\text { kampret atau kebaya } \\
\text { menanamkan rasa } \\
\text { cinta sebagai orang } \\
\text { sunda, pakaian batik } \\
\text { menerapkan bahwa } \\
\text { kita sebagai bagian } \\
\text { dari dunia supaya } \\
\text { tidak ketinggalan } \\
\text { oleh bangsa-bangsa } \\
\text { di dunia, Jum'at } \\
\text { adalah hari suci umat } \\
\text { Islam. Kemudian } \\
\text { kebijakan yang } \\
\text { dikeluarkan hari } \\
\text { Jum'at memakai } \\
\text { samping sarung dan } \\
\text { kopiah }\end{array}$ & $\begin{array}{l}\text { Semua } \\
\text { steakholder } \\
\text { sekolah }\end{array}$ & Sesuai hari & $\begin{array}{l}\text { Mengimplement } \\
\text { asikan Perbup } \\
\text { No.69 tahun } \\
2015 \text { tentang } \\
\text { pendidikan } \\
\text { berkarakter }\end{array}$ \\
\hline 15 & $\begin{array}{l}\text { Membaca surat } \\
\text { Yaasin berjamaah }\end{array}$ & $\begin{array}{l}\text { Membiasakan } \\
\text { mencintai membaca } \\
\text { Al-qur'an setiap } \\
\text { waktu }\end{array}$ & $\begin{array}{l}\text { Ks, guru, } \\
\text { staff sekolah, } \\
\text { siswa }\end{array}$ & Hari Jum'at & \\
\hline 16 & $\begin{array}{l}\text { Satu hari dalam } \\
\text { berkomunikasi } \\
\text { menggunakan } \\
\text { bahasa sunda }\end{array}$ & $\begin{array}{l}\text { Mencintai budaya } \\
\text { sunda }\end{array}$ & $\begin{array}{l}\text { Ks, guru, } \\
\text { staff sekolah } \\
\text { dan siswa }\end{array}$ & Hari Rabu & \\
\hline 17 & $\begin{array}{l}\text { Betah di imah siswa } \\
\text { mengikuti orang tua } \\
\text { untuk belajar }\end{array}$ & $\begin{array}{l}\text { Siswa merasakan } \\
\text { rasa kasih sayang } \\
\text { orang tua }\end{array}$ & Siswa & Hari Sabtu & \\
\hline
\end{tabular}




\begin{tabular}{|c|c|c|c|c|c|}
\hline NO & $\begin{array}{c}\text { NAMA } \\
\text { KEGIATAN/BEN } \\
\text { TUK PERILAKU }\end{array}$ & $\begin{array}{c}\text { PENANAMAN } \\
\text { KARAKTER/ } \\
\text { TUJUAN BUDAYA }\end{array}$ & SASARAN & WAKTU & KET. \\
\hline & $\begin{array}{l}\text { memahami kegiatan } \\
\text { orang tua }\end{array}$ & & & & \\
\hline 18 & Vokasional & $\begin{array}{l}\text { Memahami kegiatan } \\
\text { orang tua yaitu } \\
\text { pekerjaan orang } \\
\text { tuanya }\end{array}$ & $\begin{array}{l}\text { Siswa ikut } \\
\text { orangtua ke } \\
\text { tempat } \\
\text { pekerjaan } \\
\text { masing- } \\
\text { masing } \\
\end{array}$ & $\begin{array}{l}\text { Setiap hari } \\
\text { Sabtu dan } \\
\text { Minggu }\end{array}$ & \\
\hline 19 & $\begin{array}{l}\text { Kegiatan Readhaton } \\
\text { WJLRC }\end{array}$ & $\begin{array}{l}\text { Membaca cepat } \\
\text { bersama-sama } \\
\text { memahami isi bacaan } \\
\text { dan menyampaikan } \\
\text { kembali di depan } \\
\text { teman-temannya } \\
\text { tentang isi bacaan }\end{array}$ & $\begin{array}{l}\text { Siswa dan } \\
\text { guru }\end{array}$ & Sebulan sekali & \\
\hline 20 & $\begin{array}{l}\text { Sumbangan beras } \\
\text { Perelek }\end{array}$ & $\begin{array}{l}\text { Menumbuhkan rasa } \\
\text { kasih sayang/ welas } \\
\text { asih }\end{array}$ & $\begin{array}{l}\text { Siswa, guru } \\
\text { dan warga } \\
\text { sekolah }\end{array}$ & $\begin{array}{l}\text { Setiap hari } \\
\text { Kamis }\end{array}$ & \\
\hline
\end{tabular}

\section{Pandangan dan persepsi UPTD tentang Kurikulum 2013.}

Seiring dengan kebijakan pemerintah yang telah memberlakukan dan menetapkan berlakunya kurikulum 2013, maka posisi kurikulum 2013 adalah sebagai berikut:

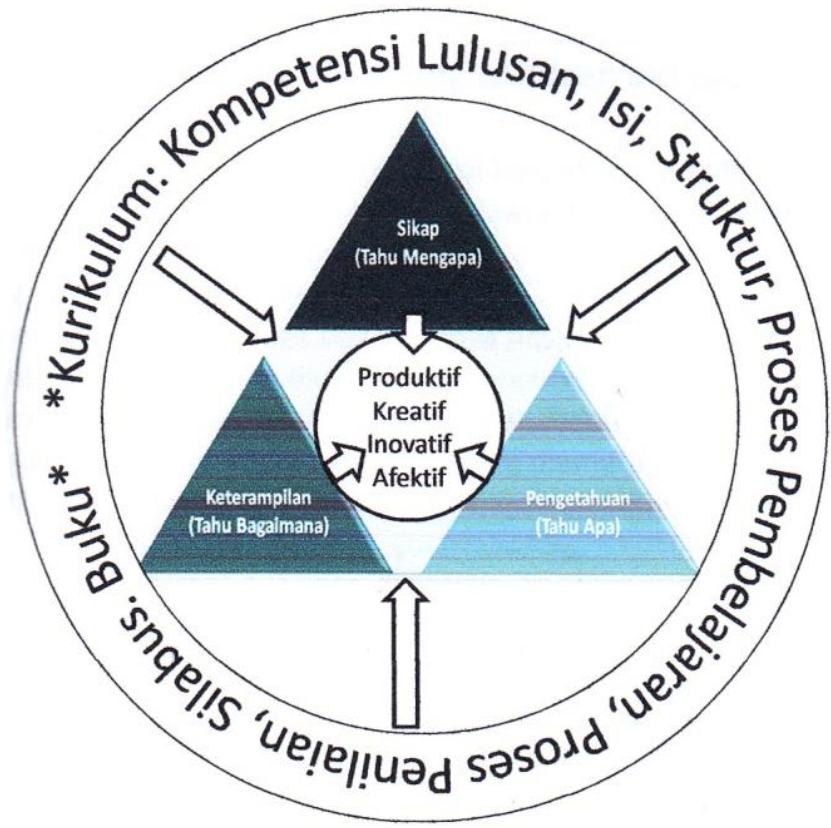

Orientasi pengembangan kurikulum 2013 didasarkan pada tantangan masa depan dan kompetensi yang diharapkan untuk masa depan, yaitu:

\begin{tabular}{|l|l|}
\hline \multicolumn{2}{|c|}{ Alasan Pengembangan Kurikulum 2013} \\
\hline \multicolumn{1}{|c|}{ Tantangan Masa Depan } & \multicolumn{1}{c|}{$\begin{array}{l}\text { Kompetensi Masa Depan Yang } \\
\text { Diharapkan }\end{array}$} \\
\hline $\begin{array}{l}\text { Globalisasi : WTO, ASEAN } \\
\text { COMMUNITY (MEA), APEC, } \\
\text { CAFTA }\end{array}$ & $\bullet \begin{array}{l}\text { Kemampuan berkomunikasi } \\
\text { Kemampuan berfikir jernih dan } \\
\text { kritis }\end{array}$ \\
\hline
\end{tabular}




\begin{tabular}{|c|c|}
\hline \multicolumn{2}{|c|}{ Alasan Pengembangan Kurikulum 2013} \\
\hline Tantangan Masa Depan & $\begin{array}{c}\text { Kompetensi Masa Depan Yang } \\
\text { Diharapkan }\end{array}$ \\
\hline $\begin{array}{ll}\text { - } & \text { Masalah Lingkungan Hidup } \\
\text { - } & \text { Kemajuan Informasi \& } \\
\text { - } & \text { Keknologi } \\
\text { - } & \text { Ekonorgensi Ilmu \&Teknologi } \\
\text { - } & \text { Kebangkitan Budaya dan } \\
\text { - } & \text { Ekonomi Kreatif } \\
\text { - } & \text { Pengeseran Ekonomi dunia } \\
\text { - } & \text { teknosains } \\
\text { - } & \text { tranforu, investasi dan } \\
& \text { pendidikan } \\
\text { - } & \text { Hasil TIMSS \& PISA }\end{array}$ & $\begin{array}{l}\text { - } \text { Kemampuan mempertimbangkan } \\
\text { - } \text { Kegi moral suatu permasalahan } \\
\text { - } \text { Kemg bertanggung jawab } \\
\text { - } \text { mengerti dan toleran terhadap } \\
\text { pandangan yang berbeda } \\
\text { - } \text { Kemampuan hidup dalam } \\
\text { masyarakat yang mengglobal } \\
\text { - Memiliki minat tinggi dalam } \\
\text { kehidupan } \\
\text { - Memiliki kesiapan untuk bekerja } \\
\text { Memiliki kecerdasan sesuai dengan } \\
\text { bakat/minat } \\
\text { Memiliki kecakapan dan } \\
\text { keterampilan dalam } \\
\text { mengoperasikan TIK. }\end{array}$ \\
\hline $\begin{array}{l}\text { Gejala/fenomena Negatif yang } \\
\text { terjadi }\end{array}$ & Persepsi Masyarakat \\
\hline $\begin{array}{ll}\text { - } & \text { Perkelaian Pelajar } \\
\text { - } & \text { Narkoba } \\
\text { - } & \text { Korupsi } \\
\text { - } & \text { Plagiarisme } \\
\text { - } & \text { Kecurangan dalam Ujian } \\
\text { - } & \text { Gejolak masyarakat } \\
\end{array}$ & $\begin{array}{l}\text { - Terlalu menitik beratkan pada } \\
\text { aspek kognitif } \\
\text { - } \quad \text { Beban peserta didik terlalu } \\
\text { berat } \\
\text { - } \quad \text { Kurang bermuatan } \\
\text { karakter/watak }\end{array}$ \\
\hline
\end{tabular}

Pandangan dan pendapat UPTD, Kepala Sekolah dan Guru, dapat digambarkan oleh peneliti sebagai berikut:

Dunia Pendidikan adalah dunia yang amat Kompleks, Menantang dan Mulia. Kompleks, mengingat spectrum pendidikan yang sangat luas tak terbatas. Menantang, karena melalui pendidikan akan menentukan masa depan anak bangsa. Mulia, karena melalui pendidikan diarahkan untuk memanusiakan manusia.

Basis pengembangan kurikulum di dasarkan pada vissi dan missi kemendiknas 2014, yaitu "terselenggaranya layanan prima pendidikan nasional untuk membentuk insan Indonesia yang cerdas komprehensif “.

Visi diatas, diwjudkan kedalam missi kemendiknas 2010 - 2014 yang disebut sebagai missi $5 \mathrm{~K}$, yaitu:

M1. Meningkatkan Ketersediaan layanan Pendidikan

M2. Meningkatkan Keterjangkauan layanan Pendidikan

M3. Meningkatkan Kualitas/Mutu dan Relevansi Layanan Pendidikan

M4. Meningkatkan Kesetaraan dalam memperoleh Layanan Pendidikan

M5. Meningkatkan Kepastian/Keterjaminan Memperoleh Layanan Pendidikan 
Pendidikan berbasis budaya, merupakan pendidikan yang bersifatnkomprehensif, yaitu pendidikan yang memuat ilmu pengetahuan dan budi pekerti (akhlak, karakter, kreativitas inovatif)

\section{KESIMPULAN}

Generasi muda atau peserta didik yang akan menjadi pemimpin masa depan, harus dapat memimpin bangsa ini bukan hanya cerdas OTAK, tetapi juga WATAK. Generasi yang bisa disebut sebagai C - GENERATION. Sebuah generasi yang yang benar-benar telah melek TIK, dan mampu memanfaatkannya secara benar atau sesuai dengan norma dan nilai-nilai yang ada dalam kehidupan peserta didik.

Pendidikan budaya dan karakter diberikan dengan cara-cara alamiah. Peserta didik telah tumbuh dan berkembang dari generasi yang telah melek TIK.

Diperlukan peran para pemangku pendidikan secara berkesinambungan, melalui keteladanan dalam proses pembelajarannya, sehingga budaya dan karakter itu berubah menjadi cara-cata ilmiah yang membuat para guru tidak bias melepaskan diri dari 5K (Konvergensi. Kontekstual, Kolaborasi, Konektivitas dan Konten Kreatif).

\section{REFERENSI}

Depdiknas. (2013), Kurikulum 2013. Handout, Jakarta. Direktorat Jenderal Pendidikan Dasar dan Menengah, Depdinas.

Gall, M.D., Gall, J.P., Borg, W.R., (2003), Educational Research An Introduction. Boston, New York, San Francisco, Mexsico city, Montreal, Toronto, London, Madrid, Munich, Sydney.

Keputusan Mendiknas Nomor 053/U/2001 tentang pedoman penyusunan Standar Pelayanan Minimal Persekolahan Bidang Pendidikan Dasar dan Menengah

Permendiknas Nomor 22 tahun 2006 tentang Standar Isi untuk Satuan Pendidikan Dasar dan Menengah

Sukmadinata, N.S., (2002), Pengembangan Kurikulum Teori dan Praktek, Bandung Remaja Rosda Karya

; Kurikulum dan Pembelajaran Kompetensi, Bandung : Kesuma Karya ; Metode Penelitian Pendidikan, Bandung: Remaja Rosda Karya

Undang-Undang Nomor 14 tahun (2005) tentang Guru dan Dosen

Undang-Undang Nomor 20 Tahun (2003) tentang Sistem Pendidikan Nasional 